\title{
Lipid Clearing in Premature Infants during Continuous Heparin Infusion: Role of Circulating Lipases
}

\author{
HADA ZAIDAN, RAMASUBBAREDDY DHANIREDDY, MARGIT HAMOSH, \\ GUNILLA BENGTSSON-OLIVECRONA, AND PAUL HAMOSH \\ Department of Pediatrics and Department of Physiology and Biophysics, Georgetown University Medical School, \\ Washington, DC; Department of Pediatrics, Louisiana State Medical Center, Shreveport, Louisiana; and \\ Department of Medical Chemistry, University of Umea, Umea, Sweden
}

\begin{abstract}
The nature of the lipases released into the circulation during low level continuous infusion of heparin (1 unit/ml total parenteral nutrition) and after bolus heparin injection (10 units $/ \mathrm{kg})$ was investigated in a group of 11 low birth weight infants (gestational age 27-34 wk, and postnatal age of 7-26 days) receiving total parenteral nutrition with Intralipid $(0.5 \mathrm{~g} / \mathrm{kg})$. Hepatic lipase and extrahepatic lipoprotein lipase were differentiated with the aid of an antibody specific for human hepatic lipase. The data show that continuous low level heparin infusion leads to a constant baseline postheparin lipolytic activity of $0.77 \pm$ $0.18 \mu \mathrm{mol}$ free fatty acids released per milliliter serum per hour. Bolus heparin injection leads to peak lipolytic activity levels of $3.77 \pm 0.46 \mu \mathrm{mol}$ free fatty acids per milliliter serum per hour, $10 \mathrm{~min}$ after injection. About two-thirds of the total postheparin lipolytic activity was of the hepatic type during low level continuous infusion or after bolus injection of heparin. (Pediatr Res 19: 23-25, 1985)
\end{abstract}

\section{Abbreviations}

PHLA, postheparin lipolytic activity

TPN, total parenteral nutrition

LPL, lipoprotein lipase

HL, hepatic lipase

FFA, free fatty acids

Low birth weight infants are often unable to feed orally and are maintained on TPN for extended periods of time. A major source of energy during TPN is Intralipid, a $10 \%$ soybean oil emulsion containing high levels of unsaturated fatty acids (18). Intralipid is cleared from the circulation in a similar way to that of naturally occurring chylomicrons $(8,19)$, i.e. the lipid is hydrolyzed at the capillary endothelial surface prior to uptake of triglyceride-fatty acids by the tissues. The lipases active at the capillary endothelium are readily released into the circulation by heparin administration, where they are called PHLA. PHLA contains two distinct lipases of different origin (16): lipoprotein lipase $(9,14)$, released from the endothelium of adipose tissue,

Received November 16, 1983; accepted July 11, 1984.

Address correspondence to Dr. Margit Hamosh, Department of Pediatrics, Georgetown University Medical School, 3800 Reservoir Road, NW, Washington, DC 20007.

This study was presented at the Annual Meeting of the Society for Pediatric Research, Washington, DC, May 1983 and published in abstract form (Pediatr Res 17:297A, 1983). heart, lung, and skeletal muscle, and $\operatorname{HL}(14,15)$, released mainly from liver capillaries. These two lipases differ in that LPL requires apoprotein C-II for optimal activity, and is inhibited by high salt concentrations and by protamine sulfate, while HL does not require the protein cofactor and is not inhibited by high salt concentration. The main substrates for LPL are chylomicrons and very low density lipoproteins $(9,14)$. It appears that the HL acts on other types of lipoproteins, high-density lipoproteins (15, 17) and perhaps small very low-density lipoproteins (5). The purpose of this study was to measure the contribution of LPL and HL to the PHLA of premature infants.

\section{METHODS}

Subjects. A group of 11 nonicteric premature infants receiving TPN were studied at Louisiana State University Hospital in Shreveport, LA. The standard medical care in the intensive care nursery of this hospital includes the continuous administration of low levels of heparin, 1 unit $/ \mathrm{ml}$ iv fluids. The amount of heparin given was directly related to the amount of parenteral fluids administered. TPN with Intralipid (Cutter, Berkeley, CA) was not started until 5-10 days after birth, or until phototherapy was discontinued. Intralipid administration was started at a rate of $0.25 \mathrm{~g} / \mathrm{kg}$ infused during $8-12 \mathrm{~h}$ for the first 2 days. The amount of lipid infused was increased by increments of $0.25 \mathrm{~g} /$ $\mathrm{kg}$ every other day to a maximum of $2-2.5 \mathrm{~g} / \mathrm{kg}$ given over a $16-$ $\mathrm{h}$ period daily. The infants had a gestational age of 27-34 wk and a postnatal age of 7-26 days at the time of study (Table 1); birth weights ranged between $720-1740 \mathrm{~g}$, only one infant was small for gestational age. None of the infants was heparinized, and all were stable at the time of study. On the day of study, the infants were given a bolus heparin injection $(10$ units $/ \mathrm{kg}$ ) for maximal release of endothelial lipases, followed immediately by infusion of Intralipid $0.5 \mathrm{~g} / \mathrm{kg}$, for $4 \mathrm{~h}$. No other changes in iv fluids were made, including infusion of the small standard amounts of heparin. Blood specimens were obtained at 0,10 , $20,30,120$, and $240 \mathrm{~min}$ of infusion. The 0 time samples were obtained prior to the bolus heparin injection. The blood specimens were placed on ice, and the serum was immediately separated by centrifugation in a refrigerated centrifuge in order to avoid in vitro lipolysis. All serum specimens were stored at $-70^{\circ}$ $\mathrm{C}$ until analysis. These studies were approved by the Committee on Human Research of the Medical Center. Informed consent was obtained from the parents before enrollment of the infants in the study.

Preparation of purified human HL and of the rabbit antibody against this enzyme. HL was prepared from freshly drawn human postheparin plasma by affinity chromatography on heparin- 
Table 1. Clinical data on infants

\begin{tabular}{|c|c|c|c|c|c|c|c|}
\hline \multirow[b]{2}{*}{ Infant } & \multirow[b]{2}{*}{ Sex } & \multirow[b]{2}{*}{$\begin{array}{c}\text { Gestational } \\
\text { age/wk }\end{array}$} & \multirow[b]{2}{*}{$\begin{array}{l}\text { Birth wt } \\
\text { (g) }\end{array}$} & \multirow{2}{*}{$\begin{array}{l}\text { Intralipid } \\
\text { received } \\
\text { prior to } \\
\text { study }(\mathrm{g})\end{array}$} & \multicolumn{3}{|c|}{ At study } \\
\hline & & & & & Wt (g) & $\begin{array}{c}\text { Age } \\
\text { (days) }\end{array}$ & $\begin{array}{l}\text { Intralipid } \\
\text { infused } \\
\text { (g) }\end{array}$ \\
\hline $\mathrm{BO}$ & $\mathrm{F}$ & 27 & 720 & 15.6 & 780 & 26 & 0.39 \\
\hline $\mathrm{TA}$ & $\mathrm{F}$ & 28 & 1420 & 1.2 & 1280 & 7 & 0.64 \\
\hline BR & $\mathrm{F}$ & 29 & 1020 & 4.2 & 900 & 11 & 0.45 \\
\hline SN & $\mathrm{F}$ & 30 & 1410 & 19.5 & 1260 & 19 & 0.63 \\
\hline $\mathrm{SH}$ & $F$ & 30 & 1320 & 11.0 & 1020 & 19 & 0.51 \\
\hline WI & $F$ & 30 & 1220 & 21.5 & 1160 & 17 & 0.58 \\
\hline SM & $\mathrm{M}$ & 27 & 780 & 5.2 & 660 & 11 & 0.33 \\
\hline $\mathrm{JA}^{*}$ & $\mathrm{M}$ & 29 & 720 & 5.6 & 680 & 17 & 0.33 \\
\hline $\mathrm{McG}$ & $\mathrm{M}$ & 32 & 1740 & 3.8 & 1480 & 7 & 0.74 \\
\hline BA & M & 32 & 1260 & 0 & 1680 & 26 & 0.84 \\
\hline GA & $\mathrm{M}$ & 34 & 1700 & 0 & 1620 & 9 & 0.81 \\
\hline
\end{tabular}

* Small for gestational age.

Sepharose. The enzyme was eluted by a gradient of $\mathrm{NaCl}$ in 20 $\mathrm{mM}$ Tris- $\mathrm{Cl} \mathrm{pH} 8.5$ containing $20 \%$ (w/v) glycerol. The peak of $\mathrm{HL}$ activity eluted at about $0.7 \mathrm{M} \mathrm{NaCl}$. To remove traces of LPL the material was then mixed with anti-LPL immunoglobulins prepared by adsorption on protein A-Sepharose of a rabbit antiserum raised against bovine milk LPL. This antiserum crossreacted with human LPL (10). After $4 \mathrm{~h}$ at $4^{\circ} \mathrm{C}$ the mixture was diluted with 3 volumes of the buffer with glycerol and then applied to a column of N-desulfated, acetylated heparin-Sepharose (4). The enzyme was eluted as described above for the first column. The final preparation of HL had a specific activity of $150 \mu \mathrm{mol}$ fatty acids released $/ \mathrm{min} / \mathrm{mg}$ protein and showed two bands on polyacrylamide gel electrophoresis in sodium dodecyl sulfate. This material was used for immunization of a rabbit; about $50 \mu \mathrm{g}$ was used for each injection. Serum from several bleedings were combined and used as anti-HL antiserum in this study. This antiserum could completely inhibit HL activity in human postheparin plasma but did not affect the activity of LPL purified from human postheparin plasma, bovine milk, or rat postheparin plasma. On double diffusion in agarose plates against human preheparin plasma no precipitates were seen, demonstrating that the antiserum did not react with any major plasma protein.

Specimen analysis. All the sera were analyzed for lipolytic activities, triglyceride, and free fatty acid (FFA) levels according to methods previously described $(10,20)$. PHLA, LPL, and HL activities, were measured by hydrolysis of tri-9, 10(n) $\left[{ }^{3}-\mathrm{H}\right]$ oleylglycerol (Amersham, England) in a gum arabic stabilized emulsion (10). Lipolytic activity was expressed as $\mu$ mol FFA produced per milliliter serum per hour. LPL activity was measured after inactivation of HL by rabbit antibody against purified human HL. The reaction was stopped and the FFA produced were extracted and quantitated as described by Belfrage and Vaughan (2).

Serum FFA were measured by the $\left[{ }^{63}\right] \mathrm{NiCl}_{2}$ micromethod (11) on $10 \mu \mathrm{l}$ of serum, and triglycerides were quantitated enzymatically using $3 \mu \mathrm{l}$ serum in a Micro Centrifugal Analyzer (13) (Instrumentation Laboratories, Lexington, MA).

\section{RESULTS}

Data on the infants studied (six girls and five boys), gestational age, birth weight, age at study, and amount of Intralipid received prior to the study are given in Table 1 .

We have previously shown that in infants who receive TPN without "on line heparin," lipolytic activity is not detectable in the circulation prior to heparin administration and disappears completely $120 \mathrm{~min}$ after bolus heparin injection (7). The continuous infusion of small amounts of heparin ( $1 \mathrm{unit} / \mathrm{ml}$ iv fluid) produced a detectable baseline PHLA (Fig. 1). Administration of a bolus of 10 units $/ \mathrm{kg}$ of heparin, led to the previously observed $(7,20)$ maximal release of lipolytic enzymes within 10 min after heparin injection (Fig. 1). Under our assay conditions LPL constitued about one-third of the total PHLA, while HL was the major component, two-thirds of the circulating PHLA (Table 2). Lipase activity levels (PHLA and LPL) were higher with Intralipid as substrate in the assay system $(7,20)$ than with the triolein-gum-arabic emulsions. The proportional contribution of LPL and HL to total PHLA in the infants' serum was, however, not changed by the type of lipid emulsion used.

The triglyceride concentration rose gradually during Intralipid infusion from the baseline value of $56 \mathrm{mg} / \mathrm{dl}$ to stabilize at about $110 \mathrm{mg} / \mathrm{dl}$ at $2 \mathrm{~h}$ of infusion. The FFA values reached a $1 \mu \mathrm{mol} /$

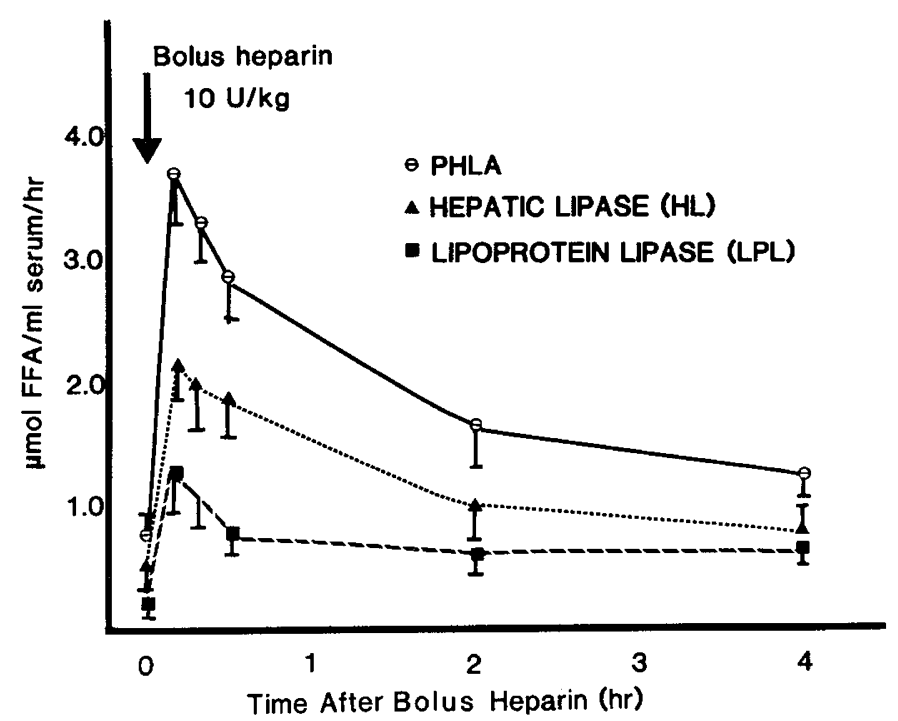

Fig. 1. Total PHLA, LPL, and HL activities in serum of very low birth weight infants maintained on TPN with Intralipid. All infants received continuous on line heparin ( $1 \mathrm{unit} / \mathrm{ml}$ iv fluids). At the beginning of the 4-h study period each infant received a bolus injection of 10 units/ $\mathrm{kg}$ heparin, for maximal release of endothelial LPL and HL. Intralipid was infused at a rate of $0.5 \mathrm{~g} / \mathrm{kg} / 4 \mathrm{~h}$, starting at 0 time. Lipase activity was measured before and after inhibition of HL by specific antibody.

Table 2. HL, triglyceride, and FFA levels during Intralipid infusion*

\begin{tabular}{cccc}
\hline $\begin{array}{c}\text { Time after bolus } \\
\text { heparin } \\
(10 \text { units/kg) }\end{array}$ & $\begin{array}{c}\text { HL } \\
\text { injection }(\mathrm{min})\end{array}$ & $\begin{array}{c}\text { Triglyceride } \\
(\mathrm{mg} / \mathrm{dl})\end{array}$ & $\begin{array}{c}\mathrm{FFA} \\
(\mu \mathrm{mol} / \mathrm{ml})\end{array}$ \\
\hline 0 & $61 \pm 13.3$ & $56.4 \pm 9.4$ & $0.69 \pm 0.09$ \\
& $(29-94)$ & $(37.4-138.8)$ & $(0.34-1.32)$ \\
10 & $65 \pm 8.7$ & $84.3 \pm 11.4$ & $1.03 \pm 0.14$ \\
& $(33-89)$ & $(53.0-166.5)$ & $(0.48-1.87)$ \\
20 & $66 \pm 9.2$ & $82.8 \pm 13.4$ & $0.92 \pm 0.13$ \\
& $(38-93)$ & $(49.7-181.8)$ & $(0.54-1.86)$ \\
30 & $66 \pm 6.7$ & $89.8 \pm 11.9$ & $1.01 \pm 0.10$ \\
& $(34-85)$ & $(51.7-178.3)$ & $(0.41-1.75)$ \\
120 & $65 \pm 8.5$ & $118.6 \pm 13.0$ & $1.04 \pm 0.14$ \\
& $(35-90)$ & $(57.4-201.9)$ & $(0.54-1.85)$ \\
240 & $55 \pm 8.3$ & $110.4 \pm 14.4$ & $1.10 \pm 0.21$ \\
& $(18-71)$ & $(58.6-207.1)$ & $(0.63-2.46)$ \\
\hline
\end{tabular}

* Data are mean \pm SEM and ranges (in parentheses).

All infants received continuous infusion of heparin $(1 \mathrm{unit} / \mathrm{ml}$ infusion fluids). At the beginning of the 4-h study period each infant received a bolus injection of 10 units $/ \mathrm{kg}$ heparin. Intralipid $0.5 \mathrm{~g} / \mathrm{kg}$ was infused during the 4-hr study period starting at 0 time. 
$\mathrm{ml}$ level at $10 \mathrm{~min}$ post Intralipid infusion and remained stable throughout the $4 \mathrm{~h}$ of the study (Table 2).

\section{DISCUSSION}

This study shows that an average of $63 \%$ of total PHLA released into the circulation of premature infants is of hepatic origin.

We have shown previously that a continuous infusion of very small levels of heparin ( $1 \mathrm{unit} / \mathrm{ml}$ iv fluid) maintains an appreciable and constant level of PHLA in the circulation (20). This in turn stabilizes the triglyceride level at about $100 \mathrm{mg} / \mathrm{dl}(20)$ as compared to $180 \mathrm{mg} / \mathrm{dl}$ in infants who receive only a single bolus heparin injection without continuous heparin infusion (7). In the present study, in which all infants also received continuous heparin infusion ( $1 \mathrm{unit} / \mathrm{ml}$ iv fluid), the serum triglyceride concentration at the end of $4 \mathrm{~h}$ of Intralipid infusion was 110 $\mathrm{mg} / \mathrm{dl}$, which is one-third lower than the triglyceride levels of infants who received Intralipid without continuous on line heparin infusion (7). The improvement in triglyceride clearing is associated with an increase in circulating FFA. The molar ratio of FFA to albumin at peak PHLA levels was $3.28 \pm 0.32$, lower that 4 , the level at which albumin-bound bilirubin is displaced and could cause encephalopathy (6).

The peak level of lipolytic activity released $10 \mathrm{~min}$ after bolus heparin injection (Fig. 1) is similar in infants who receive continuous low level heparin infusion (1 unit/ml iv fluid) and infants who receive TPN without continuous heparin administration (20) indicating that lipase reserves are not depleted by continuous low level heparin administration.

The ratio of HL to LPL in serum PHLA is similar in our group of very low birth weight infants (Table 2) to that recently reported in older children (1). Using similar techniques to differentiate between the two lipases, Asayama et al. (1) report that hepatic lipase amounts to $62 \%$ of serum PHLA in 8 to 9 -yr-old children. The ratio between the lipase activities is also similar to that reported for adults $(14,16)$, but both activities seem to be lower in infants.

We believe that the circulating, heparin-released lipases are responsible for the enhanced rate of triglyceride clearing in premature infants who receive TPN with Intralipid and heparin. Normally, LPL hydrolyses triglyceride-rich lipoproteins, and presumably also Intralipid, at the capillary endothelium $(9,14)$. The activity of LPL varies widely between tissues and this determines where the lipid is taken up. After its release to the blood by heparin, LPL catalyzes the same hydrolysis but it can no longer direct the uptake of the fatty acids to the appropriate tissues. Thus, the increased rate of triglyceride clearing is achieved at the expense of a loss of control over where the fatty acids are taken up.

There was a higher activity of HL than of LPL in the blood after heparin administration. What contribution this HL makes to hydrolysis of the Intralipid triglycerides in the circulating blood is not clear. In an in vitro system the HL is fully capable of attacking Intralipid, but in blood this activity is subject to strong inhibition by high-density lipoproteins (3), which are a preferred substrate for HL. An interesting, but unresolved, question is whether the HL may attack the Intralipid phospholipids, some of which are present as liposome-like structures (4).

More studies are required on the effect of long-term heparin and Intralipid administration to premature infants before any recommendations for best clinical management can be made. We may assume that efficient utilization of Intralipid in very low birth weight infants could be achieved by administration of Intralipid together with low levels of heparin and carnitine, the former to improve lipid clearing and the latter to facilitate the oxidation of the FFA released. The possible risk of hemorrhagic diathesis in premature infants given continuous heparin infusion has also to be considered, although we did not encounter any hemorrhagic complications with this small amount of heparin.

Acknowledgement. This study was supported by NIH Grant HD-15631, and by Grant 13X-727 from the Swedish Medical Research Council. We thank Ms. Marguerite Starry for secretarial help.

\section{REFERENCES}

1. Asayama K, Kato K, Anemiya S, Nozaki Y 1982 Postheparin plasma lipases in patients with hepatic glycogenosis. Horm Metabol Res 14:555

2. Belfrage $P$, Vaughan M 1969 Simple liquid-liquid partition system for isolation of labeled oleic acid from mixtures with glycerides. J Lipid Res 10:341

3. Bengtsson $G$, Olivecrona T 1980 The hepatic heparin releasable lipase binds to high density lipoproteins. FEBS Lett 119:290

4. Bengtsson G, Olivecrona $\Upsilon$, Hook M, Risenfeld J, Lindahl U 1980 Interaction of lipoprotein lipase with native and modified heparin-like polysaccharides. Biochem J 189:625

5. Breckenridge WC, Little JA, Alaupovic P, Wang CS, Kuksis A, Kakis G, Lindgren F, and Gardiner G 1982 Lipoprotein abnormalities associated with a familial deficiency of hepatic lipase. Atherosclerosis 45:161

6. Brodersen R 1982 Physical chemistry of bilirubin: binding to macromolecules and membranes. In: Heirweigh KPM, Brown SB (eds) Bilirubin. Vol I. Chemistry. CRC Press, Boca Raton, FL

7. Dhanireddy R, Hamosh M, Sivasubramanian KN, Choudhry P, Scanlon JW, Hamosh P 1981 Postheparin lipolytic activity and Intralipid clearance in very low birthweight infants. J Pediatr 98:617

8. Hallberg D 1965 Elimination of exogenous lipids from the blood stream. An experimental methodological and clinical study in dog and man. Acta Physiol Scand 65(suppl 254):1

9. Hamosh M, Hamosh P 1983 Lipoprotein lipase: its physiological and clinical significance. Mol Asp Med 5:199

10. Hernell O, Egelrud T, Olivecrona T 1975 Serum-stimulated lipases (lipoprotein lipases). Immunological cross reaction between the bovine and the human enzymes. Biochim Biophys Acta 381:234

11. Ho RJ 1970 Radiochemical assay of long-chain fatty acids using ${ }^{63} \mathrm{Ni}$ : as tracer. Anal Biochem 36:105

12. Huttunen JK, Ehnholm C, Kinnunen PKJ, Nikkila EA 1975 An immunochemical method for the selective measurement of two triglyceride lipases in human post-heparin plasma. Clin Chim Acta 63:335

13. Instrumentation laboratory 1980 Operator's Manual Fluorescence/Light Scatter, Micro Centrifugal Analyzer, sections 2 and 8

14. Jackson RL 1983 Lipoprotein lipase and hepatic lipase. In: Boyer PD (ed) The Enzymes. Vol XVI. Academic Press, New York, pp 141-181

15. Jansen H, Hulsman WC 1980 Heparin-releasable (liver) lipase(s) may play a role in the uptake of cholesterol by steroid-secreting tissues. Trends Biochem Sci $5: 265$

16. Krauss RM, Levy RI, Frederickson DS 1974 Selective measurement of two lipase activities in post-heparin plasma from normal subjects and patients with hyperlipoproteinemia. J Clin Invest 54:1107

17. Kuusi T, Saarinen P, Nikkila E 1980 Evidence for the role of hepatic endothelial lipase in the metabolism of plasma high density lipoproteins in man. Atherosclerosis 36:589

18. Olegard R, Gustafson A, Kjellmer I, Victorin L 1975 Nutrition in low-birthweight infants. III. Lipolysis and free fatty acid elimination after intravenous administration of fat emulsion. Acta Paediatr Scand 64:745

19. Rossner S, Eklund B, Freyschuss U 1976 Elimination of parenterally administered fat. Studies on removal sites for Intralipid in normo- and hyperlipidaemic subjects. Acta Chir Scand Suppl 466:56

20. Zaidan H, Dhanireddy R, Hamosh M, Pramanik A, Choudhry P, Hamosh P 1982 Effect of continuous heparin administration on Intralipid clearing in very low birth weight infants. J Pediatr 101:599 